\title{
Papers
}

\section{Interpregnancy interval and risk of preterm birth and neonatal death: retrospective cohort study}

\author{
Gordon C S Smith, Jill P Pell, Richard Dobbie
}

\begin{abstract}
Objective To determine whether a short interval between pregnancies is an independent risk factor for adverse obstetric outcome.

Design Retrospective cohort study.

Setting Scotland.

Subjects 89143 women having second births in 1992-8 who conceived within five years of their first birth.

Main outcome measures Intrauterine growth restriction (birth weight less than the 5th centile for gestational age), extremely preterm birth (24-32 weeks), moderately preterm birth (33-36 weeks), and perinatal death.

Results Women whose subsequent interpregnancy interval was less than six months were more likely than other women to have had a first birth complicated by intrauterine growth restriction (odds ratio $1.3,95 \%$ confidence interval 1.1 to 1.5 ), extremely preterm birth (4.1,3.2 to 5.3$)$, moderately preterm birth (1.5, 1.3 to 1.7$)$, or perinatal death (24.4, 18.9 to 31.5$)$. They were also shorter, less likely to be married, and more likely to be aged less than 20 years at the time of the second birth, to smoke, and to live in an area of high socioeconomic deprivation. When the outcome of the second birth was analysed in relation to the preceding interpregnancy interval and the analysis confined to women whose first birth was a term live birth $(n=69055)$, no significant association occurred (adjusted for age, marital status, height, socioeconomic deprivation, smoking, previous birth weight vigesimal, and previous caesarean delivery) between interpregnancy interval and intrauterine growth restriction or stillbirth. However, a short interpregnancy interval ( $<6$ months) was an independent risk factor for extremely preterm birth (adjusted odds ratio 2.2, 1.3 to 3.6), moderately preterm birth (1.6, 1.3 to 2.0$)$, and neonatal death unrelated to congenital abnormality (3.6, 1.2 to 10.7$)$. The adjusted attributable fractions for these associations were $6.1 \%, 3.9 \%$, and $13.8 \%$. The associations were very similar when the analysis was confined to married non-smokers aged 25 and above. Conclusions A short interpregnancy interval is an independent risk factor for preterm delivery and neonatal death in the second birth.
\end{abstract}

\section{Introduction}

Several studies have shown that women with a very short interval between pregnancies are at increased risk of complications such as preterm birth, neonatal death, and intrauterine growth restriction. ${ }^{1-10}$ However, these studies do not clarify whether the associations are due to confounding effects of adverse obstetric history or to demographic factors. Women with very short interpregnancy intervals are more likely to have had complications such as perinatal death, preterm birth, and intrauterine growth restriction in their first pregnancy. ${ }^{11}$ A short interpregnancy interval is also associated with known demographic risk factors for complications of pregnancy. ${ }^{12}{ }^{13}$ Many previous studies of the association between interpregnancy interval and the risk of adverse outcome have lacked information on maternal demographic factors and have had either no information on the outcome of previous pregnancies or minimal information. None of the studies that were powered to detect differences in rare but important outcomes, such as perinatal death and extremely preterm birth, had data on key obstetric and demographic confounders. ${ }^{6}{ }^{9}{ }^{10}$ We report the relation between interpregnancy interval and the outcome of first and second births in a cohort of 89143 women.

\section{Methods}

\section{Data sources}

The Scottish Morbidity Record collects information on clinical and demographic characteristics and outcomes for all patients discharged from Scottish maternity hospitals. The register is subjected to regular quality assurance checks and has been greater than 99\% complete since the late 1970s. ${ }^{14}$ We linked records from the register to records from the Scottish Stillbirth and Infant Death Enquiry, a national register that routinely classifies all perinatal deaths in Scotland. It is virtually $100 \%$ complete and has been described in detail elsewhere. ${ }^{15}{ }^{16}$ We also linked the records from different pregnancies in the same women. All linkages were performed as previously described. ${ }^{17}$

\section{Study cohort}

The population studied consisted of all second births in Scotland in 1992-8. The study focused on births in 1992-8 as the Scottish Morbidity Record database included smoking status only from 1992 onwards. When studying the relation between interpregnancy
Department of Obstetrics and Gynaecology, Cambridge University, Box 223 The Rosie Hospital, Cambridge CB2 2QQ

Gordon C S Smith professor

Department of Public Health, Greater Glasgow NHS Board,

Glasgow

Jill P Pell consultant

Information and Statistics Division, Common Services Agency, Edinburgh Richard Dobbie senior statistician

Correspondence to: G C S Smith gcss2@cam.ac.uk

bmj.com 2003;327:313 
interval and the outcome of the first pregnancy, we used exclusion criteria (both pregnancies) of multiple pregnancy, delivery outside the range 24-43 weeks' gestation, and birth weight less than $500 \mathrm{~g}$. We also excluded cases in which the interpregnancy interval was negative or implausibly short, a discrepancy existed between the documented mode of delivery in the first record and the previous caesarean delivery field in the second record, or the number of previous spontaneous or therapeutic abortions differed between the first and second birth record. The last of these processes excluded cases in which the records were discrepant (fewer losses documented for the second birth) and cases in which the woman had experienced losses between the two births (more losses documented for the second birth). These inclusions and exclusions identified the first study group.

We analysed the relation of interpregnancy interval to the outcome of the second birth in a subgroup of the main cohort. We defined this subgroup by excluding cases in which the first birth was outside the range 37-43 weeks, the first birth was a perinatal or infant death, or the birth weight of the first child was less than $1500 \mathrm{~g}$. We also excluded cases in which data were missing on potential confounders in the second pregnancy record: maternal age, marital status, height, deprivation category, or smoking status. We also excluded cases in which the birth weight vigesimal of the first pregnancy was missing. These inclusions and exclusions identified the second study group.

\section{Definitions}

Maternal characteristics

In the comparison of risk of adverse obstetric outcome, we considered the following demographic factors as possible confounders: socioeconomic deprivation, smoking, maternal age, and maternal height; their classification has been defined elsewhere. ${ }^{18}$ We also included marital status, defined as the status documented at the time of booking for antenatal care and categorised into married and non-married.

\section{Obstetric characteristics}

We defined first births as either first pregnancies or births preceded only by pregnancies that resulted in abortion. We defined second births as having been preceded by one pregnancy that did not result in abortion. We defined gestational age at birth as the number of completed weeks of gestation based on the estimated delivery date contained in the clinical record. Over the study period the vast majority of estimates of gestational age in the United Kingdom incorporated ultrasound measurements taken in the first half of pregnancy. ${ }^{19}$ We defined interpregnancy interval as the interval from the first birth until the estimated date of the last menstrual period before the second pregnancy, expressed in completed months. We calculated the ultrasound corrected date of the last menstrual period by subtracting the gestational age at birth from the date of delivery. In order to avoid bias in categorisation of interpregnancy interval, we used the categories used by a previous large scale study. ${ }^{7}$

We categorised birth weight into sex specific and gestational age specific vigesimals (20 equal groups) derived from live births among the whole population.
We defined a small for gestational age baby as a liveborn baby with a birth weight in the smallest vigesimal (that is, 0 to 5 th centile), and the denominator was all live births. We defined very preterm delivery as live births between 24 and 32 weeks' gestation inclusive, and the denominator was all live births at or after 24 weeks' gestation. We defined moderately preterm delivery as live births between 33 and 36 weeks' gestation inclusive, with a denominator of all live births at or after 33 weeks' gestation. We defined spontaneous preterm birth as vaginal birth at the given gestational age, excluding cases in which labour was induced. We defined stillbirth as delivery of a dead baby at or after 24 weeks' gestational age, and the denominator was all births at or after 24 weeks' gestational age. We defined neonatal death as death of a liveborn infant in the first four weeks of life, and the denominator was all live births.

\section{Perinatal deaths}

We defined deaths caused by congenital anomaly as any structural or genetic defect incompatible with life or potentially treatable but causing death. We classified stillbirths as antepartum (deaths before the onset of labour) or intrapartum (deaths during labour). We classified the cause of antepartum stillbirth according to a modified version of the Wigglesworth hierarchical system, ${ }^{20}$ which is described in detail elsewhere. ${ }^{16} \mathrm{We}$ classified perinatal deaths into four mutually exclusive categories: $(a)$ all deaths related to fetal abnormality or rhesus isoimmunisation; (b) unexplained stillbirths; (c) all other stillbirths; and (d) all other neonatal deaths (excluding category $(a))$.

\section{Statistical analyses}

We summarised continuous variables by the median and interquartile range and used the Mann-Whitney U test to make comparisons between groups. We made univariate comparisons of dichotomous data by using the $\chi^{2}$ test $(>5$ observations in all cells) or Fisher's exact test ( $\leq 5$ observations in one or more cells). The $P$ values for all hypothesis tests were two sided, and we set statistical significance at $\mathrm{P}<0.05$. We used multivariate logistic regression analysis to assess the risk of adverse obstetric outcome. We did both univariate and multivariate analyses on only those records with no missing values for any of the maternal covariates included in the multivariate model. We used the Hosmer and Lemeshow test to assess the goodness of fit of logistic regression models. ${ }^{21}$ We assessed the statistical significance of interaction terms by using the likelihood ratio test and assumed significance of interactions at $\mathrm{P}<0.01$. We defined the attributable fraction as $\operatorname{Pr}($ exposed $/$ disease $) *(1-1 /$ relative risk $)$. This can be conceptualised as the proportion of cases that would have been prevented if the exposure did not exist in a population. We calculated adjusted attributable fractions after multivariate logistic regression by using the method of Greenland and Drescher. ${ }^{22}$ We used the Stata software package, version 7.0, for all statistical analyses.

\section{Results}

The figure outlines the selection of the two study groups. Approximately $5.4 \%$ of the cohort had an interpregnancy interval of less than six months. 
Women who subsequently had a short interpregnancy interval were more likely to have experienced complications in their first pregnancy (table 1). Compared with women who had an interpregnancy interval of 18-23 months, those with an interval of less than six months had a $30-50 \%$ excess of intrauterine growth restriction and moderately preterm birth in their first pregnancy, a fourfold excess of extremely preterm birth, and a greater than 20-fold excess of perinatal deaths. An excess of extremely preterm first births existed among women whose subsequent interpregnancy interval was 2-5 years.

All analyses of the outcome of the second birth were confined to the subgroup of women whose first birth was a term live birth. Even among this group, at the time of their second delivery, women with a short interval between their first and second pregnancy were more likely to be aged less than 20, to smoke, and to live in an area of high deprivation and were less likely to be married, to be aged greater than 35 , and to live in an area of low socioeconomic deprivation (table 2).

On univariate analysis of obstetric outcome in the second birth, women with a short interpregnancy interval were more likely to have an extremely preterm birth, a moderately preterm birth, or a neonatal death (table 3). The strength of these associations was attenuated by adjustment for maternal age, marital status, height, socioeconomic deprivation category, smoking, previous birth weight vigesimal, and previous caesarean section, but significant associations persisted in multivariate analysis. The adjusted attributable fractions for these associations were $6.1 \%$ (95\% confidence interval $1.9 \%$ to $10.2 \%)$ for extremely preterm birth, $3.9 \%$ (1.3\% to $4.2 \%)$ for moderately preterm birth, and $13.8 \%(0.2 \%$ to $25.6 \%$ ) for neonatal death unrelated to fetal abnormality. The excess of preterm second births persisted when the analysis was confined to spontaneous preterm births. An interpregnancy interval of less than six months was associated with an increased risk (compared with an interpregnancy interval of 18-23 months) of spontaneous preterm birth, both 24-32 weeks (adjusted odds ratio $2.2,95 \%$ confidence interval 1.2 to 4.1 ) and 33-36 weeks (1.6, 1.2 to 2.2). The associations between interpregnancy interval and unexplained stillbirth were virtually identical when estimated using time to event methods (data not shown).

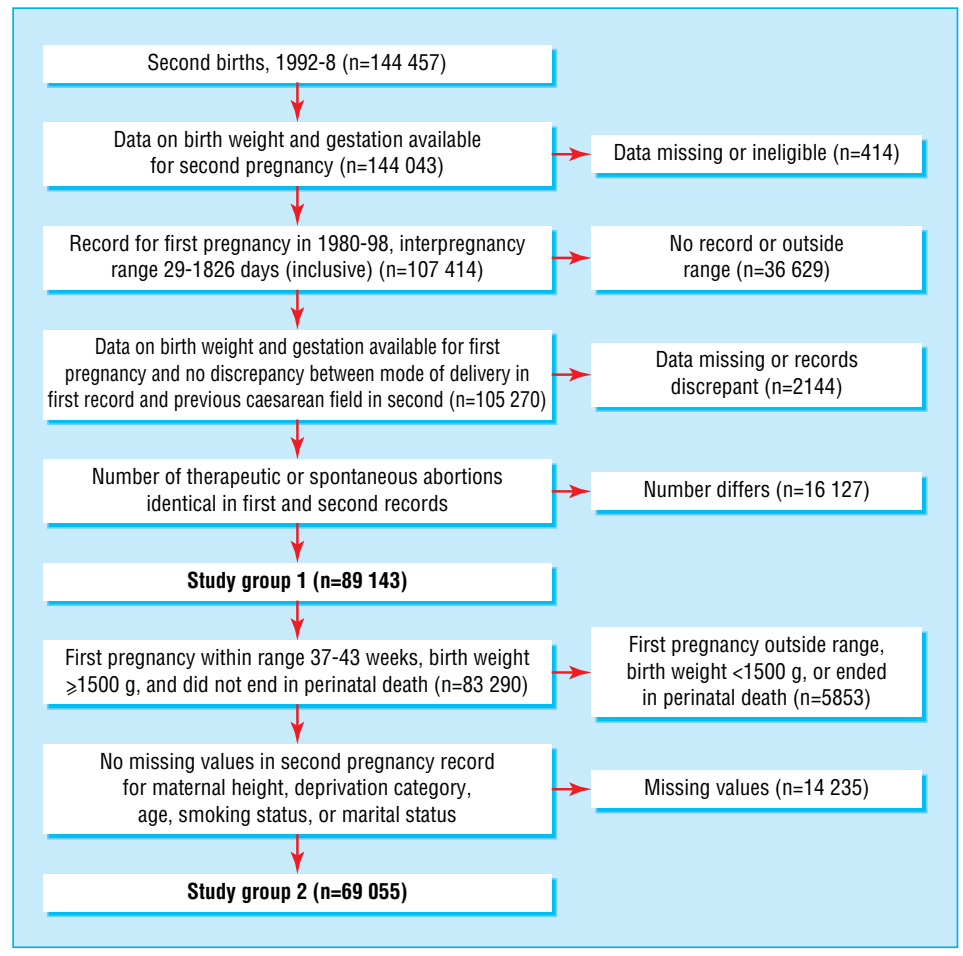

Flow diagram of cohort selection

We explored the relations between interpregnancy interval, maternal age, and other maternal factors and the outcome of the second birth in more detail. The attenuation of the association between interpregnancy interval and adverse outcome in multivariate analysis was principally due to the effect of adjustment for age (table 4). The odds ratio for interpregnancy interval adjusted for age alone was very similar to the odds ratio adjusted for age plus the other maternal covariates. Maternal age less than 20 years at the time of the second birth was strongly associated with preterm birth and neonatal death. The association remained statistically significant in multivariate analysis but was attenuated by adjustment for both interpregnancy interval and other maternal factors. No statistically significant interactions existed between interpregnancy interval and maternal age, marital

Table 1 Outcome of first pregnancy in relation to interval between first and second pregnancies ( $n=89$ 143)

\begin{tabular}{|c|c|c|c|c|c|c|c|c|c|}
\hline \multirow[b]{3}{*}{ Outcome of first pregnancy } & \multicolumn{9}{|c|}{ Interpregnancy interval* } \\
\hline & \multicolumn{2}{|c|}{ 1-5 months } & \multicolumn{2}{|c|}{ 6-11 months } & \multicolumn{2}{|c|}{ 12-17 months } & \multirow{2}{*}{$\begin{array}{c}\begin{array}{c}18-23 \\
\text { months* }\end{array} \\
\text { No (\%) }\end{array}$} & \multicolumn{2}{|c|}{ 24-59 months } \\
\hline & No $(\%)$ & $\begin{array}{c}\text { Odds ratio } \\
\text { (95\% Cl) }\end{array}$ & No $(\%)$ & $\begin{array}{c}\text { Odds ratio } \\
(95 \% \mathrm{Cl})\end{array}$ & No $(\%)$ & $\begin{array}{c}\text { Odds ratio } \\
(95 \% \mathrm{Cl})\end{array}$ & & No (\%) & $\begin{array}{c}\text { Odds ratio } \\
(95 \% \mathrm{Cl})\end{array}$ \\
\hline No of births & 4816 & - & 11927 & - & 15771 & - & 15014 & 41615 & - \\
\hline Birth weight $<5$ th centile & $298(6.6)$ & $1.3(1.1$ to 1.5$)$ & $613(5.2)$ & $1.0(0.9$ to 1.1$)$ & $804(5.1)$ & $1.0(0.9$ to 1.1$)$ & $768(5.1)$ & $2347(5.6)$ & $1.1(1.0$ to 1.2$)$ \\
\hline \multicolumn{10}{|l|}{ Preterm delivery: } \\
\hline 24-32 weeks & $146(3.2)$ & 4.1 (3.2 to 5.3$)$ & $181(1.5)$ & $1.9(1.5$ to 2.4$)$ & $155(1.0)$ & $1.2(1.0$ to 1.6$)$ & $120(0.8)$ & $458(1.1)$ & $1.4(1.1$ to 1.7$)$ \\
\hline 33-36 weeks & $257(5.9)$ & 1.5 (1.3 to 1.7$)$ & $570(4.9)$ & $1.2(1.1$ to 1.4$)$ & $662(4.3)$ & $1.1(1.0$ to 1.2$)$ & $592(4.0)$ & $1830(4.4)$ & $1.1(1.0$ to 1.2$)$ \\
\hline \multicolumn{10}{|l|}{ Perinatal death: } \\
\hline All causes† & $481(10.0)$ & 24.4 (18.9 to 31.5$)$ & $247(2.0)$ & 4.6 (3.5 to 6.1$)$ & $103(0.6)$ & $1.4(1.1$ to 2.0$)$ & $68(0.4)$ & $120(0.3)$ & $0.6(0.5$ to 0.9$)$ \\
\hline Fetal abnormality or rhesus & $71(1.5)$ & 15.0 (8.6 to 26.1$)$ & $38(0.3)$ & $3.2(1.8$ to 5.8$)$ & $21(0.1)$ & $1.3(0.7$ to 2.6$)$ & $15(0.1)$ & $26(0.1)$ & $0.6(0.3$ to 1.2$)$ \\
\hline Unexplained stillbirth & $188(3.9)$ & 30.5 (19.2 to 48.3$)$ & $87(0.7)$ & 5.5 (3.4 to 9.0$)$ & $37(0.2)$ & $1.8(1.0$ to 3.0$)$ & $20(0.1)$ & $36(0.1)$ & $0.6(0.4$ to 1.1$)$ \\
\hline All other stillbirths & $109(2.3)$ & 20.4 (12.2 to 34.1$)$ & $55(0.5)$ & 4.1 (2.4 to 7.0$)$ & $21(0.1)$ & 1.2 (0.6 to 2.2$)$ & $17(0.1)$ & $24(0.1)$ & $0.5(0.3$ to 0.9$)$ \\
\hline All other neonatal deaths & $110(2.3)$ & 23.4 (13.6 to 40.1$)$ & $65(0.5)$ & 5.5 (3.1 to 9.6$)$ & $23(0.2)$ & 1.5 (0.8 to 2.8$)$ & $15(0.1)$ & $34(0.1)$ & $0.8(0.4$ to 1.5$)$ \\
\hline
\end{tabular}

All percentages calculated relative to appropriate denominators (see methods).

*Reference category for odds ratios was women with interpregnancy interval of 18-23 months.

tSeven perinatal deaths were not classified. 
Table 2 Demographic factors at time of second pregnancy in relation to interpregnancy interval in women with previous term live birth ( $n=69$ 055). Values are numbers (percentages)

\begin{tabular}{|c|c|c|c|c|c|c|c|}
\hline & \multicolumn{5}{|c|}{ Interpregnancy interval (months) } & \multirow[b]{2}{*}{ Total ( $n=69055)$} & \multirow[b]{2}{*}{$P$ value } \\
\hline & $1-5(n=3282)$ & 6-11 $(n=8999)$ & $12-17(n=12220)$ & $18-23(n=11793)$ & $24-59(n=32761)$ & & \\
\hline \multicolumn{8}{|l|}{ Height $(\mathrm{cm})$ : } \\
\hline$<155$ & $349(10.6)$ & $843(9.3)$ & $1068(8.7)$ & $1125(9.5)$ & $3614(11.0)$ & $6990(10.1)$ & \multirow{3}{*}{$<0.001$} \\
\hline $155-170$ & $2654(80.9)$ & $7160(79.6)$ & $9868(80.8)$ & $9398(79.7)$ & $26299(80.3)$ & $55379(80.2)$ & \\
\hline$>170$ & $279(8.5)$ & 1005 (11.2) & $1284(10.5)$ & $1270(10.8)$ & $2848(8.7)$ & $6686(9.7)$ & \\
\hline \multicolumn{8}{|l|}{ Age (years): } \\
\hline$<20$ & $547(16.7)$ & $669(7.4)$ & $501(4.1)$ & $278(2.4)$ & $234(0.7)$ & $2229(3.2)$ & \multirow{3}{*}{$<0.001$} \\
\hline $20-35$ & $2624(80.0)$ & 7899 (87.8) & $11120(91.0)$ & 10961 (92.9) & $30655(93.6)$ & $63259(91.6)$ & \\
\hline$>35$ & $111(3.4)$ & $431(4.8)$ & $599(4.9)$ & $554(4.7)$ & $1872(5.7)$ & $3567(5.2)$ & \\
\hline \multicolumn{8}{|l|}{ Marital status: } \\
\hline Married & $1949(59.4)$ & $6714(74.6)$ & $9681(79.2)$ & $9615(81.5)$ & $25315(77.3)$ & $53274(77.2)$ & \multirow{2}{*}{$<0.001$} \\
\hline Other & $1333(40.6)$ & $2285(25.4)$ & $2539(20.8)$ & $2178(18.5)$ & $7446(22.7)$ & $15781(22.8)$ & \\
\hline \multicolumn{8}{|l|}{ Deprivation category: } \\
\hline 1 (least deprived) & $484(14.8)$ & 1919 (21.3) & $2933(24.0)$ & $2720(23.1)$ & $6045(18.4)$ & $14101(20.4)$ & \multirow{3}{*}{$<0.001$} \\
\hline $2-4$ & 1915 (58.4) & $5397(60.0)$ & $7242(59.3)$ & $7104(60.2)$ & $19809(60.5)$ & $41467(60.0)$ & \\
\hline 5 (most deprived) & $883(26.9)$ & $1683(18.7)$ & $2045(16.7)$ & $1969(16.7)$ & $6907(21.1)$ & 13487 (19.5) & \\
\hline \multicolumn{8}{|l|}{ Smoking status: } \\
\hline Non-smoker & $1839(56.0)$ & $6078(67.5)$ & $8560(70.0)$ & $8309(70.5)$ & $21279(65.0)$ & $46065(66.7)$ & \multirow{3}{*}{$<0.001$} \\
\hline Ex-smoker & $193(5.9)$ & $536(6.0)$ & $797(6.5)$ & $759(6.4)$ & $2533(7.7)$ & $4818(7.0)$ & \\
\hline Smoker & $1250(38.1)$ & 2385 (26.5) & $2863(23.4)$ & $2725(23.1)$ & 8949 (27.3) & $18172(26.3)$ & \\
\hline
\end{tabular}

status, height, socioeconomic deprivation category, smoking, previous birth weight vigesimal, or previous caesarean section in predicting adverse obstetric outcome in the second pregnancy. The strengths of the associations were virtually identical when confined to married non-smokers aged 25 or above: in this group an interpregnancy interval of less than six months was associated with an odds ratios of 2.8 (1.3 to 5.9) for extremely preterm birth and 1.7 (1.2 to 2.4 ) for moderately preterm birth.

We considered the possibility that misclassification of gestational age may have affected the results by examining the association between interpregnancy interval and absolute values of birth weight in the second pregnancy. An interpregnancy interval of less than six months was associated with an increased risk of delivering a low birth weight neonate (adjusted odds ratio $1.5,1.2$ to 1.8 ) or a very low birth weight neonate (1.9, 1.0 to 3.4$)$. We considered the possibility that excluding the 14255 cases with missing values for potential confounders from the second study group may have affected our results. However, univariate analysis of second pregnancy outcomes including these cases showed positive associations between a one to five month interval (18-23 months as reference group) and extreme preterm birth (odds ratio 2.8, 1.9 to 4.2$)$, moderate preterm birth (2.0, 1.6 to 2.4$)$, and neonatal death unrelated to congenital abnormality $(3.2,1.3$ to 7.9$)$.

\section{Discussion}

The main finding of this study is that in women having a second birth a short preceding interpregnancy inter-

Table 3 Crude and adjusted odds ratios for interpregnancy interval and the outcome of the second pregnancy $(n=69055)$

Interpregnancy interval ${ }^{\star}$

\begin{tabular}{|c|c|c|c|c|c|c|c|c|c|c|c|c|c|}
\hline \multirow{4}{*}{$\begin{array}{l}\text { Outcome of } \\
\text { second } \\
\text { pregnancy }\end{array}$} & \multicolumn{13}{|c|}{ minerpregnantity interval } \\
\hline & \multirow[b]{3}{*}{ No $(\%)$} & \multicolumn{2}{|c|}{ 1-5 months ( $\mathrm{n=3282)}$} & \multicolumn{3}{|c|}{ 6-11 months ( $n=8999)$} & \multicolumn{3}{|c|}{ 12-17 months ( $\mathrm{n}=12$ 220) } & \multirow{3}{*}{$\begin{array}{c}\begin{array}{c}18-23 \\
\text { months* }\end{array} \\
(\mathrm{n}=11793)\end{array}$} & \multicolumn{3}{|c|}{ 24-59 months ( $\mathrm{n}=32$ 761) } \\
\hline & & \multicolumn{2}{|c|}{ Odds ratio $(95 \% \mathrm{CI})$} & \multirow[b]{2}{*}{ No (\%) } & \multicolumn{2}{|c|}{ Odds ratio $(95 \% \mathrm{Cl})$} & \multirow[b]{2}{*}{ № $(\%)$} & \multicolumn{2}{|c|}{ Odds ratio $(95 \% \mathrm{CI})$} & & \multirow[b]{2}{*}{ No (\%) } & \multicolumn{2}{|c|}{ Odds ratio $(95 \% \mathrm{Cl})$} \\
\hline & & Crude & Adjusted† & & Crude & Adjusted† & & Crude & Adjusted† & & & Crude & Adjusted $†$ \\
\hline $\begin{array}{l}\text { Birth weight } \\
<5 \text { th centile }\end{array}$ & $\begin{array}{c}99 \\
(3.0)\end{array}$ & $\begin{array}{c}1.1 \\
(0.9 \text { to } 1.4)\end{array}$ & $\begin{array}{c}0.8 \\
\text { (0.7 to } 1.1)\end{array}$ & $\begin{array}{l}234 \\
(2.6)\end{array}$ & $\begin{array}{c}1.0 \\
(0.8 \text { to } 1.1)\end{array}$ & $\begin{array}{c}0.9 \\
(0.8 \text { to } 1.1)\end{array}$ & $\begin{array}{l}325 \\
(2.7)\end{array}$ & $\begin{array}{c}1.0 \\
(0.8 \text { to } 1.1)\end{array}$ & $\begin{array}{c}1.0 \\
\text { (0.8 to } 1.2)\end{array}$ & $\begin{array}{l}321 \\
(2.7)\end{array}$ & $\begin{array}{c}987 \\
(3.0)\end{array}$ & $\begin{array}{c}1.1 \\
(1.0 \text { to } 1.3)\end{array}$ & $\begin{array}{c}1.0 \\
(0.9 \text { to } 1.1)\end{array}$ \\
\hline \multicolumn{14}{|c|}{ Preterm delivery: } \\
\hline $\begin{array}{l}24-32 \\
\text { weeks }\end{array}$ & $\begin{array}{c}32 \\
(1.0)\end{array}$ & $\begin{array}{c}3.1 \\
(1.9 \text { to } 4.9)\end{array}$ & $\begin{array}{c}2.2 \\
(1.4 \text { to } 3.6)\end{array}$ & $\begin{array}{c}46 \\
(0.5)\end{array}$ & $\begin{array}{c}1.6 \\
\text { (1.0 to } 2.4)\end{array}$ & $\begin{array}{c}1.4 \\
\text { (0.9 to } 2.2)\end{array}$ & $\begin{array}{c}48 \\
(0.4)\end{array}$ & $\begin{array}{c}1.2 \\
\text { (0.8 to } 1.9)\end{array}$ & $\begin{array}{c}1.2 \\
(0.8 \text { to } 1.8)\end{array}$ & $\begin{array}{c}38 \\
(0.3)\end{array}$ & $\begin{array}{l}122 \\
(0.4)\end{array}$ & $\begin{array}{c}1.2 \\
(0.8 \text { to } 1.7)\end{array}$ & $\begin{array}{c}1.1 \\
(0.8 \text { to } 1.6)\end{array}$ \\
\hline $\begin{array}{l}33-36 \\
\text { weeks }\end{array}$ & $\begin{array}{c}130 \\
(4.0)\end{array}$ & $\begin{array}{c}2.0 \\
(1.6 \text { to } 2.4)\end{array}$ & $\begin{array}{c}1.6 \\
(1.3 \text { to } 2.0)\end{array}$ & $\begin{array}{l}218 \\
(2.4)\end{array}$ & $\begin{array}{c}1.2 \\
(1.0 \text { to } 1.4)\end{array}$ & $\begin{array}{c}1.1 \\
\text { (0.9 to } 1.3)\end{array}$ & $\begin{array}{l}280 \\
(2.3)\end{array}$ & $\begin{array}{c}1.1 \\
(0.9 \text { to } 1.3)\end{array}$ & $\begin{array}{c}1.1 \\
(0.9 \text { to } 1.3)\end{array}$ & $\begin{array}{l}244 \\
(2.1)\end{array}$ & $\begin{array}{c}800 \\
(2.5)\end{array}$ & $\begin{array}{c}1.2 \\
(1.0 \text { to } 1.4)\end{array}$ & $\begin{array}{c}1.2 \\
(1.0 \text { to } 1.3)\end{array}$ \\
\hline \multicolumn{14}{|l|}{ Perinatal death: } \\
\hline $\begin{array}{l}\text { Fetal } \\
\text { abnormality } \\
\text { or rhesus }\end{array}$ & $\begin{array}{c}6 \\
(0.2)\end{array}$ & $\begin{array}{c}1.4 \\
\text { (0.6 to } 3.7)\end{array}$ & $\begin{array}{c}1.2 \\
(0.5 \text { to } 3.3)\end{array}$ & $\begin{array}{c}12 \\
(0.1)\end{array}$ & $\begin{array}{c}1.0 \\
\text { (0.5 to 2.2) }\end{array}$ & $\begin{array}{c}1.0 \\
\text { (0.5 to 2.1) }\end{array}$ & $\begin{array}{c}17 \\
(0.1)\end{array}$ & $\begin{array}{c}1.1 \\
\text { (0.5 to 2.2) }\end{array}$ & $\begin{array}{c}1.2 \\
\text { (0.5 to } 2.2 \text { ) }\end{array}$ & $\begin{array}{c}15 \\
(0.1)\end{array}$ & $\begin{array}{c}45 \\
(0.1)\end{array}$ & $\begin{array}{c}1.1 \\
\text { (0.6 to } 1.9)\end{array}$ & $\begin{array}{c}1.1 \\
(0.6 \text { to } 2.0)\end{array}$ \\
\hline $\begin{array}{l}\text { Unexplained } \\
\text { stillbirth }\end{array}$ & $\begin{array}{c}7 \\
(0.2)\end{array}$ & $\begin{array}{c}1.6 \\
\text { (0.6 to } 3.8)\end{array}$ & $\begin{array}{c}1.2 \\
(0.5 \text { to } 3.0)\end{array}$ & $\begin{array}{c}10 \\
(0.1)\end{array}$ & $\begin{array}{c}0.8 \\
\text { (0.4 to } 1.8)\end{array}$ & $\begin{array}{c}0.7 \\
\text { (0.3 to 1.7) }\end{array}$ & $\begin{array}{c}20 \\
(0.2)\end{array}$ & $\begin{array}{c}1.2 \\
(0.6 \text { to } 2.3)\end{array}$ & $\begin{array}{c}1.2 \\
(0.6 \text { to } 2.3)\end{array}$ & $\begin{array}{c}16 \\
(0.1)\end{array}$ & $\begin{array}{c}55 \\
(0.2)\end{array}$ & $\begin{array}{c}1.2 \\
\text { (0.7 to } 2.2 \text { ) }\end{array}$ & $\begin{array}{c}1.2 \\
(0.7 \text { to } 2.1)\end{array}$ \\
\hline $\begin{array}{l}\text { All other } \\
\text { stillbirths }\end{array}$ & $\begin{array}{c}5 \\
(0.2)\end{array}$ & $\begin{array}{c}2.6 \\
(0.8 \text { to } 8.1)\end{array}$ & $\begin{array}{c}2.3 \\
(0.7 \text { to } 7.2)\end{array}$ & $\begin{array}{c}9 \\
(0.1)\end{array}$ & $\begin{array}{c}1.7 \\
(0.6 \text { to } 4.5)\end{array}$ & $\begin{array}{c}1.7 \\
(0.6 \text { to } 4.5)\end{array}$ & $\begin{array}{c}12 \\
(0.1)\end{array}$ & $\begin{array}{c}1.7 \\
(0.7 \text { to } 4.2)\end{array}$ & $\begin{array}{c}1.7 \\
(0.7 \text { to } 4.3)\end{array}$ & $\begin{array}{c}7 \\
(0.1)\end{array}$ & $\begin{array}{c}27 \\
(0.1)\end{array}$ & $\begin{array}{c}1.4 \\
\text { (0.6 to } 3.2)\end{array}$ & $\begin{array}{c}1.2 \\
(0.5 \text { to } 2.8)\end{array}$ \\
\hline $\begin{array}{l}\text { All other } \\
\text { neonatal } \\
\text { deaths }\end{array}$ & $\begin{array}{c}9 \\
(0.3)\end{array}$ & $\begin{array}{c}5.4 \\
(1.9 \text { to } 15.2)\end{array}$ & $\begin{array}{c}3.6 \\
\text { (1.2 to } 10.7)\end{array}$ & $\begin{array}{c}10 \\
(0.1)\end{array}$ & $\begin{array}{c}2.2 \\
(0.8 \text { to } 6.0)\end{array}$ & $\begin{array}{c}1.9 \\
(0.7 \text { to } 5.2)\end{array}$ & $\begin{array}{c}2 \\
(0.0)\end{array}$ & $\begin{array}{c}0.3 \\
(0.1 \text { to } 1.6)\end{array}$ & $\begin{array}{c}0.3 \\
\text { (0.1 to } 1.5)\end{array}$ & $\begin{array}{c}6 \\
(0.1)\end{array}$ & $\begin{array}{c}20 \\
(0.1)\end{array}$ & $\begin{array}{c}1.2 \\
\text { (0.5 to } 3.0)\end{array}$ & $\begin{array}{c}1.2 \\
(0.5 \text { to } 3.0)\end{array}$ \\
\hline
\end{tabular}

All percentages calculated relative to appropriate denominators (see methods)

${ }^{*}$ Reference category for odds ratios was women with interpregnancy interval of 18-23 months.

†Adjusted for maternal age, marital status, height, socioeconomic deprivation category, smoking, previous birth weight vigesimal, and previous caesarean section. 
Table 4 Interpregnancy interval, maternal age, other demographic factors, and risk of adverse obstetric outcome

\begin{tabular}{|c|c|c|c|c|c|c|c|c|}
\hline \multirow[b]{2}{*}{ Outcome } & \multicolumn{4}{|c|}{ Odds ratios $(95 \% \mathrm{CI})$ for interpregnancy interval $<6$ months } & \multicolumn{4}{|c|}{ Odds ratios $(95 \% \mathrm{Cl})$ for age $<20$ years } \\
\hline & Crude & Adjusted 1 & Adjusted 2 & Adjusted 3 & Crude & Adjusted 1 & Adjusted 2 & Adjusted 3 \\
\hline Delivery 24-32 weeks & 3.1 (1.9 to 4.9$)$ & 2.3 (1.4 to 3.8 ) & 2.5 (1.5 to 4.0$)$ & 2.2 (1.4 to 3.6$)$ & 4.0 (2.6 to 6.2 ) & $3.2(2.0$ to 5.1$)$ & 2.6 (1.6 to 4.2$)$ & $2.0(1.2$ to 3.4$)$ \\
\hline Delivery $33-36$ weeks & $2.0(1.6$ to 2.4$)$ & 1.7 (1.3 to 2.1$)$ & $1.7(1.4$ to 2.1$)$ & $1.6(1.3$ to 2.0$)$ & $2.3(1.9$ to 2.9$)$ & $2.2(1.7$ to 2.7$)$ & $1.6(1.3$ to 2.1$)$ & $1.5(1.2$ to 2.0$)$ \\
\hline $\begin{array}{l}\text { Neonatal death } \\
\text { unrelated to } \\
\text { congenital } \\
\text { abnormality or } \\
\text { rhesus }\end{array}$ & 5.4 (1.9 to 15.2$)$ & 3.8 (1.3 to 11.0$)$ & 4.3 (1.5 to 12.3$)$ & 3.6 (1.2 to 10.7$)$ & 8.4 (3.2 to 22.2 ) & $5.6(2.0$ to 15.9$)$ & $5.0(1.6$ to 15.7$)$ & 3.5 (1.0 to 11.6$)$ \\
\hline
\end{tabular}

val was an independent risk factor for extremely preterm birth, moderately preterm birth, and neonatal death not due to congenital abnormality. The association occurred even among women whose first pregnancy was a term live birth and persisted after adjustment for maternal age, marital status, height, socioeconomic deprivation category, smoking, previous birth weight vigesimal, and previous caesarean section. The association was specific to preterm birth and neonatal death, as no association existed between a short interpregnancy interval and the risk of delivering a growth restricted infant and the confidence intervals were sufficiently narrow to exclude even a weak association. When we examined the outcome of all first births in relation to the subsequent interpregnancy interval, women with a short interpregnancy interval had a significant excess of intrauterine growth restriction, preterm birth, and perinatal deaths in their first births. Indeed, approximately $10 \%$ of women with an interval of less than six months had a first birth that had ended in perinatal death, compared with less than $1 \%$ of women with an interval of 18-23 months. These observations are consistent with previous studies and underline the importance of excluding women with complications in their first birth when examining associations between interpregnancy interval and the outcome of the second birth. ${ }^{11}$

An association has previously been shown between maternal age less than 20 years at the time of the second birth and adverse obstetric outcome. ${ }^{23}$ In the present study we could show that this association was independent of interpregnancy interval and complications of the first pregnancy. However, the association between maternal age less than 20 years and adverse outcome was attenuated by adjustment for marital status, socioeconomic deprivation category, smoking status, height, previous birth weight vigesimal, and previous caesarean section, although a statistically significant association persisted in multivariate analysis (table 4). We cannot exclude the possibility that maternal age less than 20 years is a marker for some other environmental factor. However, it is unlikely that the associations with a short interpregnancy interval were due to unmeasured or residual confounding. Firstly, after adjustment for maternal age, adjustment for other maternal factors had very little effect (table 4). Secondly, the strength of the association was virtually unchanged when we confined the analysis to married, non-smoking women aged 25 and above. Thirdly, no statistically significant first order interactions occurred between a short interpregnancy interval and other maternal factors. Finally, the association was specific for preterm birth and neonatal death. No association existed between a short interpregnancy interval and delivering a small for gestational age baby. In contrast, a high socioeconomic deprivation category (that is, more deprived) was significantly associated with delivering a small for gestational age baby in multivariate analysis (data not shown).

The lack of association between interpregnancy interval and growth restriction also suggests that the relation between a short interpregnancy interval and other adverse outcomes is unlikely to be due to depletion of maternal nutritional reserves. A specific association between a short interpregnancy interval and preterm birth is biologically plausible. The control of parturition is thought to be mediated by a two step process of activation and stimulation. ${ }^{24}$ Activation is defined as the up regulation of expression of a range of contraction associated proteins, such as $\mathrm{G}$ protein coupled receptors, in the weeks leading up to term. Stimulation is defined as the process by which synthesis and release of natural agonists for these receptors, such as prostaglandins, initiates uterine contraction. We hypothesise that failure to allow expression of contraction associated proteins to return to prepregnancy levels may be the mechanism by which a short interpregnancy interval predisposes to preterm birth.

We propose that women should be informed of a small but significantly elevated risk of preterm birth

\section{What is already known on this topic}

Women with a short interval between pregnancies are at increased risk of obstetric complications

These women also differ in their previous obstetric complications and demographic characteristics

Whether the increased risk of adverse outcome after a short interpregnancy interval is merely due to confounding by obstetric and demographic associations is unclear

\section{What this study adds}

Women with short intervals between pregnancies are much more likely to have had complicated first births and to have demographic risk factors for obstetric complications

Even among women with an uncomplicated first birth and after adjustment for maternal demographics, a short interpregnancy interval was associated an increased risk of preterm birth and neonatal death 
and perinatal death when they conceive shortly after a birth. Contraceptive advice should be targeted towards women who are most likely to have a subsequent short interpregnancy interval-namely, teenagers and women who have just experienced a perinatal loss.

Contributors: GCSS had the original concept, reviewed previous publications, undertook the statistical analyses, and wrote the initial draft of the paper. JPP interpreted the results and contributed to the draft of the paper. RD performed the linkage and extracted the data. All authors edited and approved the final version of the paper. GCSS is the guarantor.

Funding: None.

Competing interests: None declared.

1 Brody DJ, Bracken MB. Short interpregnancy interval: a risk factor for low birthweight. Am J Perinatol 1987;4:50-4.

2 Lieberman E, Lang JM, Ryan KJ, Monson RR, Schoenbaum SC. The association of inter-pregnancy interval with small for gestational age birt Obstet Cynecol 1989:74:1-5.

3 Rawlings JS, Rawlings VB, Read JA. Prevalence of low birth weight and preterm delivery in relation to the interval between pregnancies among white and black women. N Engl J Med 1995;332:69-74.

4 Adams MM, Delaney KM, Stupp PW, McCarthy BJ, Rawlings JS. The relationship of interpregnancy interval to infant birthweight and length of gestation among low-risk women, Georgia. Paediatr Perinat Epidemiol 1997;11(suppl 1):48-62.

5 Basso O, Olsen J, Knudsen LB, Christensen K. Low birth weight and preterm birth after short interpregnancy intervals. Am J Obstet Gynecol 1998;178:259-63.

6 Khoshnood B, Lee KS, Wall S, Hsieh HL, Mittendorf R. Short interpregnancy intervals and the risk of adverse birth outcomes among five racial ethnic groups in the United States. Am J Epidemiol 1998;148:798-805.

7 Zhu BP, Rolfs RT, Nangle BE, Horan JM. Effect of the interval between pregnancies on perinatal outcomes. N Engl J Med 1999;340:589-94.

8 Shults RA, Arndt V, Olshan AF, Martin CF, Royce RA. Effects of short interpregnancy intervals on small-for-gestational age and preterm births. Epidemiology 1999;10:250-4.
9 Fuentes-Afflick E, Hessol NA. Interpregnancy interval and the risk of premature infants. Obstet Gynecol. 2000:95:383-90.

10 Zhu BP, Haines KM, Le T, McGrath-Miller K, Boulton ML. Effect of the interval between pregnancies on perinatal outcomes among white and black women. Am J Obstet Gynecol 2001;185:1403-10.

11 Erickson JD, Bjerkedal T. Interpregnancy interval: association with birth weight, stillbirth, and neonatal death. J Epidemiol Community Health 1978;32:124-30.

12 Klebanoff MA. Short interpregnancy interval and the risk of low birthweight. Am J Public Health 1988;78:667-70.

13 Kaharuza FM, Sabroe S, Basso O. Choice and chance: determinants of short interpregnancy intervals in Denmark. Acta Obstet Gynecol Scand 2001;80:532-8.

14 Cole SK. Scottish maternity and neonatal records. In: Chalmers I, Mcllwaine GM, eds. Perinatal audit and surveillance. London: Royal College of Obstetricians and Gynaecologists, 1980:39-51.

15 Mcllwaine GM, Dunn FH, Howat RC, Smalls M, Wyllie MM, MacNaughton MC. A routine system for monitoring perinatal deaths in Scotland. Br J Obstet Gynaecol 1985;92:9-13.

16 Information and Statistics Division NHS Scotland. Scottish perinatal and infant mortality and morbidity report 2001. Edinburgh: Common Services Agency, 2002 (available at www.show.scot.nhs.uk/isd/sexual health spimmr/SPIMMR_-2001.pdf)

17 Kendrick S, Clarke J. The Scottish record linkage system. Health Bull (Edinb) 1993;51:72-9.

18 Smith GCS, Pell JP, Cameron AD, Dobbie R. Risk of perinatal death associated with delivery after previous caesarean section. JAMA 2002.287.2684-90.

19 Campbell S, Soothill PW. Detection and management of intrauterine growth retardation: a British approach. In: Chervenak FA, Isaacson GC, Campbell S, eds. Ultrasound in obstetrics and gynaecology, vol 2. Boston: Little Brown, 1993:1432-5.

20 Cole SK, Hey EN, Thomson AM. Classifying perinatal death: an obstetric approach. Br J Obstet Gynaecol 1986;93:1204-12.

21 Hosmer DW, Lemeshow S. Applied logistic regression. New York: John Wiley and Sons, 1989.

22 Greenland S, Drescher K. Maximum likelihood estimation of the attributable fraction from logistic models. Biometrics 1993;49:865-72.

23 Smith GCS, Pell JP. Teenage pregnancy and risk of adverse perinatal outcomes associated with first and second births: population based retrospective cohort study. BMJ 2001;323:476-9.

24 Norwitz ER, Robinson JN, Challis JR. The control of labor. N Engl J Med 1999;341:660-6.

(Accepted 18 June 2003) 